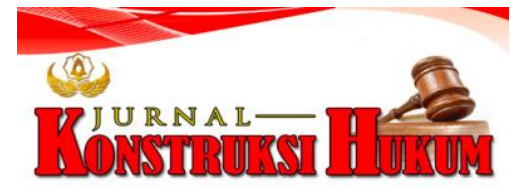

\title{
SANKSI PIDANA TERHADAP PELANGGARAN LALU LINTAS YANG MENGAKIBATKAN HILANGNYA NYAWA SESEORANG
}

\author{
Maudy Aulia Putri, I Nyoman Gede Sugiartha, Ni Made Sukaryati Karma \\ Fakultas Hukum Universitas Warmadewa, Denpasar-Bali, Indonesia \\ maudyaulia287@gmail.com, nyomansugiartha14@gmail.com, madesukaryatikarma@gmail.com
}

\begin{abstract}
Abstrak
Kemacetan di jalan semakin hari semakin meningkat, hal ini sangat berdampak pada aktivitas seseorang. Ruas jalan yang tidak sebanding dengan banyaknya jumlah kendaraan hal ini memungkinkan terjadinya kecelakaan lalu lintas. Pemicu tingginya kecelakaan lalu lintas karena masih kurangnya pemahaman masyarakat dalam berkendara. Penelitian ini bertujuan untuk menjelaskan pengaturan terhadap pelanggaran lalu lintas yang mengakibatkan hilangnya nyawa seseorang dan menjelaskan sanksi pidana terhadap pelanggaran lalu lintas yang mengakibatkan hilangnya nyawa seseorang. Metode yang digunakan adalah metode penelitian huku normatif dengan melakukan teknik pendekatan masalah perundang-undangan dan konseptual. Adapun suber data yang digunakan adalah sumber data primer dan sekunder. Penelitian ini menyimpulkan bahwa lalu lintas dan angkutan jalan sudah dijelaskan beberapa pengaturan terhadap pelanggaran lalu lintas yang termuat dalam Pasal 316 ayat 1 UULAJ. Selanjutnya dalam menjatuhkan sanksi pidana terhadap pelaku pelanggaran lalu lintas tercatat pada Pasal 310 dan 311 Undang-Undang Proses pemeriksaan perkara tindak pidana di Pengadilan Negeri dilakukan dengan penyelidikan acara cepat dan sederhana.
\end{abstract}

Kata Kunci : Lalu Lintas, Pelanggaran, Sanksi

\begin{abstract}
Congestion on the road is increasing nowadays, this has a huge impact on a person, the number of roads is not in accordance with the large number of vehicles this is a traffic accident. The trigger for traffic accidents is because people still lack understanding of how to drive. This study aims to explain traffic arrangements that occur to someone who reports someone's life and explain the criminal sanctions against traffic that reports someone's life. The method used is the method of normative legal research by using a technique of approaching the problem of invitation and conceptual. The data subsectors used are primary and secondary data sources. This study concludes that traffic and transport are ready to serve based on the assumptions contained in Article 316 paragraph 1 of the UULAJ. Criminal enforcement against traffic crime perpetrators is recorded in Articles 310 and 311 of the Law. The criminal investigation process at the District Court is carried out by means of a quick and simple investigation procedure.
\end{abstract}

Keywords: Traffic, Violation, Sanctions

\section{PENDAHULUAN}

Indonesia adalah negara yang pengendalian kekuasaan pemerintahannya didasarkan atas hukum. UU NKRI 1945 dalam Pasal 1 ayat (3) sudah dijelaskan bahwa Indonesia merupakan Negara hukum yang terdapat dalam konsep welfare state yaitu kewajiban pemerintah dalam melangsungkan misi Negara, sebagaimana tertera dalarn alinea keempat pembukaan UUD 1945. Pesatnya kendaraan semakin harinya di jalan raya terutarna pada jam tertentu sangat berpengaruh pada kemacetan di jalan raya, hal ini diakibatkan karena masih kurangnya akses jalan dan kendaraan yang semakin meningkat secara pesat setiap harinya yang menimbulkan kecelakaan lalu lintas dan tidak nyaman dalam berkendara.

Penyebab kecelakaan lalu lintas salah satunya banyak masyarakat yang kurang memaharni peraturan dalam berlalu lintas atau belum siapnya berkendara menyebabkan suatu kecelakaan yang bisa saja merugikan pengguna jalan lainnya (Marsaid et al., 2013). Pelanggaran lalu lintas adalah keadaan dimana tidak sesuainya aturan dan pelaksanaanya, dalam hal ini sudah diterapkan kepada negara dan berlaku secara sah, masyarakat sebagai pelaksanaanya dalam menyelusuri peraturan yang tertera, jika tidak maka disebut pelanggaran lalu lintas (Junef, 2014). 
Sanksi yang diberikan kepada pelaku bukan untuk pelaku merasa menderita melainkan ditujukan untuk menekankan tertib hukum, melindungi masyarakat hukum, dengan begitu pengguna jalan lebih taat dan patuh dalam berlalu lintas. UU Nomor 22 Tahun 2009 sudah menjelaskan berbagai aturan masalah kecelakaan yang menimbulkan korban luka ringan maupun berat dan mati. Untuk itu adanya undang-undang pengguna jalan sehingga lebih berhati- hati dan mengikuti kebijakan lalu lintas. Tidak sedikit yang mengabaikan kebijakan dan keselamatan pengguna jalan, perlu ditumbuhkan kesadaran akan budaya tertib berlalu lintas, melanggar rambu rambu dijalan umum jangan dianggap baik, namun tumbuhkan kesadaran bahwa tindakan itu salah.

Ada beberapa penelitian terdahulu yang relevan dengan penelitian ini yaitu (Rifki, 2014); (Alwafi Ridho Subarkah, 2018); (Jasmine, 2020) mengungkapkan bahwa Tindak pidana mengandung beberapa unsur yaitu unsur subyektif seperti kemampuan bertanggungjawab, unsur kesalahan (schuld) yang terdiri dari kealpaan dan kesengajaan serta unsur obyektif seperti perbuatan manusia, akibat dari perbuatan manusia, keadaan-keadaan dan sifat melawan hukum. Hakim dalam mengadili perkara tindak pidana kecelakaan lalu lintas harus memperhatikan sanksi yang diatur dalam kitab undangundang hukum pidana hanyalah berupa sanksi pidana penjara saja. Walaupun sudah banyak penelitian yang mengkaji tentang penelitian ini, namun sampai saat ini belum ada solusi yang tepat dalam mencegah kemacetan dan kecelakaan lalu lintas, oleh sebab itu penelitian ini dilakukan dengan tujuan untuk untuk menjelaskan pengaturan terhadap pelanggaran lalu lintas yang mengakibatkan hilangnya nyawa seseorang dan menjelaskan sanksi pidana terhadap pelanggaran lalu lintas yang mengakibatkan hilangnya nyawa seseorang

\section{METODE PENELITIAN}

Penelitian ini menggunakan penelitian hukum normatif dengan melakukan pengkajiannya dari bahanbahan aturan dan proses untuk menemukan prinsip-prinsip maupun ideologi hukum untuk menanggapi permasalahan yang dihadapi demi membentuk argumentasi, sedangkan pendekatan masalah yang digunakan yaitu pendekatan konsep hukum dan pendekatan konseptual sebagai cara memecahkan masalah yang terkait (Soekanto, 2009). Adapun sumber bahan aturan yang dipakai yaitu primer dan sekunder yaitu UUD NKRl Tahun 1945, KUHP, UU No 22 Tahun 2009, Peraturan Pemerintah Nomor 37 Tahun 2011, Peraturan pemerintah No 80 Tahun 2012. Selain itu juga berpedoman pada buku hukum, jurnal-jurnal serta artikel yang berkaitan.

\section{HASIL DAN PEMBAHASAN}

\section{Peraturan Terhadap Pelanggaran Lalu Lintas yang Mengakibatkan Hilangnya Nyawa} Seseorang

Latu Lintas adalah satu kesatuan sistem terdiri atas angkutan Jalan, jaringan, prasarana, kendaraan, pengemudi, pengguna jalan, serta pengelolanya. Adapun asas-asas mengenai pengertian lalu lintas berdasarkan Pasal 2 Undang-Undang yakni Asas transparan, akuntabel, berkelanjutan, partisipatif, bermanfaat, efisien dan efektif, seimbang, terpadu dan mandiri.

Lalu lintas sangat mendukung pembentukan dan integrasi nasional sebagai usaha mengembangkan kesejahteraan umum sebagaimana diamanatkan dalam undang-undang. Sebagai bentuk sistem pemindahan nasional, harus dikembangkan potensi dan peran untuk melancarkan keamanan, kesejahteraan, ketertiban berlalu lintas dalam rangka mendukung pembangunan ekonomi dan pengembangan ilmu pengetahuan dan teknologi, otonomi daerah, serta akuntabilitas penyelenggaraan Negara.

Lalu lintas diselenggarakan dengan tujuan mewujudkan jasa berlalu lintas yang aman dan terpadu dengan modal muatan lain sebagai dorongan perekonomian nasional, kesejahteraan umum, memperkuat persatuan kesatuan bangsa dan mampu memuliakan martabat bangsa, menciptakan etis berlalu lintas dan budaya bangsa.

Ada tiga unsur dalam berlalu lintas yakni: Manusia sebagai pengguna jalan, memiliki kemampuan atau kesiagaan yang berbeda (waktu, reaksi, konsentrasi) keadaan fisik dan psikologi, umur serta jenis kelamin dan pengaruh luar seperti cuaca, penerangan lampu dan tata ruang kendaraan yaitu benda bergerak dijalan terdiri atas kendaraan bermotor dan tidak bermotor atau digerakan oleh tenaga manusia. Jalan berfungsi sebagai lintasan dirancangkan untuk dilalui pengemudi termasuk pejalan kaki serta dibentuk untuk mengalihkan aliran dan mendukung beban muatan sehingga aman meredam angka kecelakaan. Dalam menjalankan tugas, pemerintah memiliki tujuan agar keadaan 
selamat, aman, cepat, lancar, tertib dan teratur saat berlalu lintas melalui kelola dan rekayasa lalu lintas (Asshiddiqie \& Safa'at, 2006). Manajemen dan rekayasa yaitu sealur usaha yang berupa perencanaan, pengadaan, pemasangan, pengaturan dan pemeliharaan fasilitas perlengkapan dalam rangka menyelenggarakan, mendukung dan keamanan berlalu lintas. Kegiatan di jalan diperlukan suatu peraturan yang dapat membentuk arahan bagi pengguna, peraturan berlalu lintas dijelaskan pada Pasal 316 ayat 1, meskipun peraturan sudah ada banyak pelanggaran masih terjadi dan tidak sedikit berdampak kecelakaan. Apabila seseorang melanggar maka akan dikenakan sanksi.

Sebagai Negara hukum, setiap orang terikat dengan susunan-susunan yang ada, sebagaimana semestinya dipatuhi. Untuk hal ini jika ketentuan tersebut tidak patut maka dapat diartikan bahwa yang terlibat telah melakukan suatu pelanggaran (Romli, 2000). Kelalaian adalah perilaku bertentangan pada aturan atau melanggar sesuatu berhubungan dengan hukum. Berdasarkan pengertian tersebut maka dimaksud pelanggaran lalu lintas yakni perbuatan pengguna yang mengemudikan kendaraan melawan aturan dalam berlalu lintas (Prodjodikoro, 1989). Sistem pidana mengatur perbuatan yang dilarang dan dihukum bagi siapa saja yang berbuat. Tindak pidana dibagi atas kejahatan dan pelanggaran dasarnya tidak ada perbedaan keduanya sama sama delik serta boleh diberikan sanksi. Selanjutnya dijelaskan dalam KUHP kejahatan dimuat dalam buku II Pasal 104 sampai 488, sedangkan pelanggaran disebutkan pada buku III Pasal 489- 569.

Pelanggaran terhadap hukum dapat diambil tindakan oleh kelompok yang berwajib, tanpa ada aduan dari aspek yang dirugikan. Terduga yang terbukti kesalahannya dapat dipidana mati atau penjara kurungan, denda serta pidana tambahan. Banyaknya pelanggaran yang dilakukan oleh pengguna, dengan itu pemerintah telah menata peraturan lalu lintas yang mengatur tingkah laku manusia agar tidak terjadi kecelakaan bahkan menyebabkan kerugian. Misalnya dalam berkendara pengemudi melakukan aktivitas lainnya sehingga mengganggu konsentrasi contoh menggunakan handphone saat menggunakan sepeda motor sangat berbahaya, pasalnya kebiasaan ini mengakibatkan seseorang kehilangan konsentrasi, dan tak jarang menimbulkan reaksi yang salah dan berbahaya saat terjadi hal tidak diinginkan. Selain membahayakan diri sendiri juga dapat membahayakan orang lain. Aturan pengendara dilarang melakukan kegiatan sampingan sudah disebutkan pada Pasal 106 ayat 1 Undang-Undang lalu lintas $99 \%$ orang saat kegiatan berlalu lintas melanggar batas kecepatannya atau melebihi kecepatan yang ditenrukan dengan alasan terburu-buru sehingga hat tersebut sangat rentan akan kecelakaan. Pemerintah telah menetapkan batas batas kecepatan lebih jelas disebutkan di Pasal 21 ayat 1 dan 2 Undang -Undang Lalu Lintas dan Angkutan jalan.

Rambu-rambu merupakan bagian penting kita ketahui, contohnya perlengkapan jalan, larangan, perintah, petunjuk bagi pengguna. Sering kita temukan masih ada yang melanggar rambu contohnya lampu merah, akibatnya tidak sedikit kecelakaan berakibat karena kesengajaannya menerobos lampu rnerah. Hal ini disebutkan ke dalam Pasal 287. Berdasarkan undang-undang, kecelakaan merupakan peristiwa dijalan yang tidak disangkakan menyertakan kendaraan dengan atau tanpa pengemudi jalan lain yang mengakibatkan korban manusia atau kerugian harta benda. Ada beberapa golongan kecelakaan yaitu: Ringan yaitu membuahkan kerusakan benda atau barang, Sedang yaitu membawa dampak luka ringan dan berat memicu luka hingga meninggal. Dalam membuktikan kecelakaan yang mengakibatkan kerugian materi tanpa korban jiwa maka perbuatan tersebut diartikan sebagai tindak pidana jika memenuhi faktor faktor sebagai berikut:

a) Subyek

b) Kesalahan bersifat melawan hukum (dari tindakan);

c) Suatu tindakan yang dilarang oleh undang-undang dan diancam dengan pidana

d) Waktu tempat dan keadaan

Sanksi pidana terhadap pelanggaran lalu lintas yang mengakibatkan hilangnya nyawa seseorang perbuatan pidana suatu hukuman sebab akibat, sebab adalah kasusnya, akibat adalah hukumannya. jenis yang banyak digunakan di dalam menjatuhkan hukuman terhadap seseorang yang dinyatakan bersalah dalam perbuatannya mengalami hukuman akan menerima sanksi dari pihak berwajib melalui pengadilan. Sanksi pidana bersifat mengikat terhadap perbuatan tersangka yang dapat menggangu atau membahayakan kepentingan hukum (Andrisman, 2009). Sanksi pidana sangat diperlukan, dalam kehidup bermasyarakat guna mencegah tindak kejahatan-kejahatan. Jenis-Jenis pidana yang diancam tersangka Pasal 10 KUHP ialah : 
a. Pidana Mati

Hukuman yang terberat di antara semua jenis pidana dan yang tertua, terberat dan sering dikatakan paling kejam adalah hukuman mati

b. Pidana Penjara

Pengurangan serta perampasan kemerdekaan seseorang.

c. Pidana Kurungan lebih ringan daripada pidana penjara yang diperuntukan bagi peristiwaperistiwa pidana yang lebih ringan sifatnya

d. Pidana Denda

Berupa harta benda yang jumlah ancamannya pada umumnya relatif ringan.

e. Pidana Tutupan

Pidana baru dalam KUHP diatur dalam Undang-Undang nomor 20 Tahun 1946 dan menempati urutan kelima pada jenis pidana pokok.

Hukuman atau sanksi dalam kasus ini hingga menyebabkan meninggal dunia dilihat pada Pasal 359 KUHP, pada suatu pelanggaran terdapat kealpaan, akan tetapi kebanyakan bagi kejahatankejahatan diperlukan suatu kesengajaan, disamping disengaja orang juga sudah dapat dipidana apabila kesalahan tersebut berbentuk kelalaian. Pengertian tersebut dibagi menjadi dua yaitu bentuk disengaja maupun tidak sengaja. Adapun sanksi-sanksi yang diberikan kepada penyebab musibah lalu lintas berdasarkan Pasal 359 dan 361 serta denda yang disebutkan pada Pasal 310 Undang-Undang Lalu Lintas dan Angkutan Jalan. Pemidanaan dan hukuman berdampingan dengan kehidupan seseorang di masyarakat terutama melibatkan benda paling berharga dalam kehidupan yaitu nyawa serta kemerdekaan seseorang. Dalam proses pemeriksaan persoalan pelanggaran lalu lintas berbeda dengan yang lain karena pemeriksaan acara cepat dan sederhana yakni penyidik mencatat bukti pelanggarannya dan diserahkan kepada pengadilan Negeri setempat. Namun selain hukuman ditentukan oleh pihak berwajib seringkali penyelesaiannya tidak sesuai dengan kerentuan yang berlaku. Tidak sedikit peristiwa tersebut diselesaikan di tempat dengan cara kekeluargaan kepada pelaku dan korban serta dibantu oleh polantas sebagai saksi. Tindak pidana lalu lintas dianggap pidana ringan hal tersebut karena sanksi di dalam undang-undang tersebut berupa denda, sehingga dengan begitu masyarakat sering melawan aturan tersebut (Rinto, 2014).

\section{SIMPULAN DAN SARAN}

\section{Simpulan}

Berlandaskan pembahasan mengenai permasalahan yang diungkap dalam penelitian ini, maka dapat disimpulkan bahwa pengaturan terhadap pelanggaran lalu lintas terdapat dalam Undang-Undang No 22 Tahun 2009 yang sudah menjelaskan mengenai peraturan berserta sanksi pidana dij. Dalam melakukan kegiatan berlalu lintas diperlukan suatu peraturan yang dapat menjadikan pedoman bagi pengguna jalan, walaupun berbagai peraturan telah ada masih saja pelanggaran lalu lintas sering terjadi bahkan tidak sedikit yang menyebabkan kecelakaan lalu lintas, selanjutnya sanksi bagi pelaku tindak pidana lalu mengacu pada Pada Pasal 310 dan Pasal 311 dalam undang-undang lalu lintas. Pelanggaran lalu lintas sering dianggap pidana yang ringan bagi masyarakat karena sanksi yang ada didalamnya dianggap masih mudah karena hukumannya kebanyakan berupa denda, sehingga masih berani melakukan pelanggaran lalu lintas. Selain diselesaikan secara hukum kasus lalu lintas banyak juga yang diselesaikan di tempat kejadian dengan cara kekeluargaan oleh pelaku dan korban kecelakaan.

\section{Saran}

Dari hasil penelitian di atas adapun yang menjadi saran yaitu kepada pihak yang berwenag untuk mempertegas pengaturan sanksi terhadap pelanggaran lalu lintas. Lebih terperinci dalam hal pengaturan terhadap jenis jenis pelanggaran yang ada sehingga tidak menimbulkan kekaburan norma hukum dan Sepatutnya terhadap jenis jenis pelanggaran tertentu yang menyebabkan hilangnya nyawa seseorang semestinya diberikan sanksi minimumnya. 


\section{DAFTAR PUSTAKA}

Alwafi Ridho Subarkah. (2018). Ganti Rugi terhadap Keluarga Korban Kecelakaan Lalu Lintas yang Mengakibatkan Hilangnya Nyawa Seseorang Tanpa Menghapus atau Mengurangi Pertanggungja waban Pidana. Jurnal Lex Crimen, 7(10), 88-94.

Andrisman, T. (2009). Asas-Asas dan Dasar Aturan Hukum Pidana Indonesia. Universitas Lampung. Asshiddiqie, J., \& Safa'at, A. (2006). Teori Hans Kelsen tentang Hukum. Jakarta: Konstitusi Press.

Jasmine, N. C. (2020). Pertanggungjawaban Pidana Kecelakaan Lalu Lintas Karena Penggunaan Smartphone Saat Mengemudi. Indonesian Journal of Criminal Law and Criminology (IJCLC), $1(1), 33-44$.

Junef, M. (2014). Perilaku Masyarakat terhadap Operasi Bukti Pelanggaran (Tilang) dalam Berlalu Lintas. Jurnal Widya Yustisia, 1(1), 52-60.

Marsaid, Hidayat, M., \& Ahsan. (2013). Lalu Lintas pada Pengendara Sepeda Motor di Wilayah Polres Kabupaten Malang. Jurnal Ilmu Keperawatan, 1(2), 98-112.

Prodjodikoro, W. (1989). Arns- Asas Hukum Pidana. Lombok: PT. Erecos.

Rifki, M. (2014). Tinjauan Yuridis Proses Perkara Pidana Pelanggaran Lalu Lintas. Jurnal Ilmu Hukum Legal Opinion, 2(5), 121-129.

Rinto, R. (2014). Tata Tertib Latu Lintas. Yogyakarta: Syafa Media.

Romli, A. (2000). Perbandingan Hukum Pidana. Bandung: Bandar Maju.

Soekanto, S. (2009). Penelitian Hukum Normatif. Jakarta: PT Raja Grafindo Persada. 